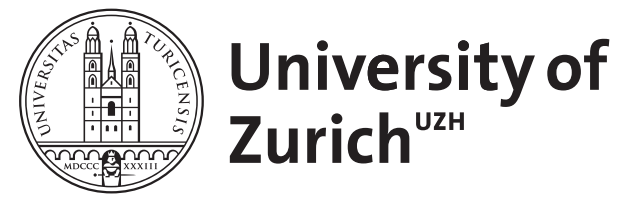
Archive

University of Zurich

University Library

Strickhofstrasse 39

CH-8057 Zurich

www.zora.uzh.ch

Year: 2014

\title{
Performativity and antagonism as keystones for a political geography of change
}

\author{
Schurr, Carolin
}

DOI: https://doi.org/10.4324/9780203094587

Posted at the Zurich Open Repository and Archive, University of Zurich ZORA URL: https://doi.org/10.5167/uzh-84735

Book Section

Published Version

Originally published at:

Schurr, Carolin (2014). Performativity and antagonism as keystones for a political geography of change. In: Glass, Michael R; Rose-Redwood, Reuben. Performativity, politics, and the production of social space. New York: Routledge, 95-120.

DOI: https://doi.org/10.4324/9780203094587 


\title{
4 Performativity and Antagonism as Keystones for a Political Geography of Change
}

\author{
Carolin Schurr
}

INTRODUCING POLITICAL CHANGE IN ECUADOR

It was while attending a regular town council meeting in the highland- 3 town of Riobamba, where I conducted research on the effect of the gen- 4 der quota law in local politics in Ecuador, ${ }^{1}$ that I became witness of the 5 following scene: $\quad 6$

The mayor and seven town councilors are sitting around a huge oval $\quad 8$ table in comfortable chairs below a prominent coat of arms of the 9 town. The other people-including me-are trying to fit in the rest of 10 the small room. The room is packed with people from the communities 11 and the urban neighborhoods. The mayor welcomes everybody, then 12 $\begin{array}{ll}\text { the secretary reads the protocol, and the session begins with a long list } & 13\end{array}$ $\begin{array}{ll}\text { of topics, mainly specific claims about infrastructure projects of certain } & 14\end{array}$ communities or neighborhoods. I am nearly dozing off, when my atten- 15 $\begin{array}{ll}\text { tion is caught by the timid speech of a man who is dressed with a pon- } & 16\end{array}$ $\begin{array}{ll}\text { cho and sombrero and hence probably identifies himself as indigenous. } & 17\end{array}$ In Spanish, he gives a hesitant account of the difficult situation in his 18 community after the access road has been severely damaged by the last 19 heavy rains. After a few minutes of speaking, the mayor interrupts the 20 man, saying that he can't do anything about it. Suddenly the indig- 21 enous woman next to the man stands up. She makes a nervous impres- 22 sion, her face blushes when she starts speaking and apologizes: "I am 23 sorry for my Spanish, but we don't know how to speak good Spanish.” 24 Immediately Edith Caranqui-the only indigenous town councilor- 25 responds to her in kichwa. Obviously she invites the woman to speak 26 in kichwa. The woman starts in a more confident voice to present her 27 claim in kichwa. While at first the mayor and the other six town coun- 28 cilors are silent due to their utter surprise at the incident, a second 29 later they start giggling, laughing, and poking fun at the woman. The 30 secretary looks stressed and asks how she is supposed to deal with this 31 incident, as she can't write the protocol in kichwa. (ethnographic notes, 32 April, 2010) 33 


\section{Carolin Schurr}

Probably, Judith Butler would have been quite enthusiastic about the "slippage" that I had witnessed in this hegemonic mestizo space where indigenous people, dress, and language have been excluded since colonialism. And so was I. But I was rather surprised that this was indeed the first incident of someone-and even more notably a woman-speaking in kichwa during a town council meeting in Riobamba. I wouldn't have been so surprised to witness a similar event in other Ecuadorian provinces. But Chimborazo, the province of which Riobamba is the capital, has one of the highest shares of indigenous population in Ecuador. I had chosen Chimborazo as a case study because of its reputation as a center of indigenous resistance. What struck me was the persistence of a colonial and postcolonial hegemony that defined politics as a white man's business and marginalized indigenous bodies, practices, and their language as inappropriate, denying their intelligibility as political subjects. The witnessed event challenged this hegemonic political order by showing that the local space of the town council could also be ordered in a different way.

Departing from this ethnographic narrative, the current chapter asks how persistency and political change are materialized in spaces of politics and how these processes can be captured in political geography. On a conceptual level, this chapter develops a theoretical framework for a political geography of change that takes into account the power relations and resulting hegemonies and acts of marginalization, which constitute the very spaces of politics. Bringing Butler's concept of performativity into dialogue with Mouffe's notion of politics as antagonism/agonism, I propose that Butler's and Mouffe's theorizing can complement each other, as they both focus attention on the everyday practices and power relations that constitute local spaces of politics. The fictitious dialogue between Butler and Mouffe to be developed in this chapter aims to contribute to ongoing discussions in political geography about the relation between politics/the political, space, and social change by addressing the following questions: How are spaces of politics brought into being through regulatory, citational practices and performances? How are hegemonic spaces of politics constructed, reproduced, and contested by counter-hegemonic political practices? What kinds of spaces of politics result from politics of antagonism and what might an agonistic space of politics look like?

My thinking about the performative dimension of political spaces adopts Mouffe's (1995: 262-263; 2005a: 8-9) useful distinction between the political and politics by differentiating between political spaces and spaces of politics. Following Mouffe, I understand political spaces as the spatial materialization of antagonism inherent in all societies. Hence, a political space is any space that is brought into being through the antagonistic relation between hegemonic and counterhegemonic subjectivities. Political spaces result from a wide set of (everyday) political 
activities, ranging from classic forms of counter-hegemonic political mobilization such as public protest to hidden forms of resistance in private spaces (e.g., Scott 1990). In contrast, spaces of politics are the outcome of a "set of practices and institutions through which an order is created" (Mouffe 2005a: 380). In democratic societies, these spaces of politics include the juridical, executive, and legislative institutions that constitute the pillars of any democracy. In my chapter, I would like to concentrate on the latter, ${ }^{2}$ showing, however, that frequently the apparently clear-cut boundary between political spaces and spaces of politics is blurred. By doing so, I aim to overcome the stark opposition found in (feminist) political geography between representative forms of democratic politics, presumed to be the source of dissatisfaction because of its state-centrism, and idealized models of alternative politics (Barnett and Low 2004: 7).

The chapter starts by revisiting scholarship in political geography that engages with questions of performativity and performative space. Then, highlighting the shortcomings of a performative approach to space as discussed in human geography, I suggest bringing the notion of performative space into dialogue with Mouffe's understanding of politics as antagonism/agonism. I develop this theoretical dialogue through my empirical research in three steps: first, drawing on the (post-)colonial history of Andean politics, I ask how a spatialized political order is established and maintained. Second, focusing on social movement struggles in Ecuador's recent history, I highlight how Butler's notion of subversion and Mouffe's concept of disarticulation are suitable to frame counterhegemonic struggles that contest the hegemonic political order. Third, taking up Mouffe's idea of agonistic pluralism, I discuss whether the Ecuadorian political imaginary of interculturalidad could actually be considered a first step toward an agonistic democracy. To sum up, I ask how performativity and antagonism can be turned into vital tools for political geography.

2

3

4

5

6

7

8

9

10

11

12

13

14

15

16

17

18

19

20

21

22

23

24

25

26

27

28

29

30

31

32

33

THINKING PERFORMATIVE SPACES OF POLITICS THROUGH ANTAGONISM $\quad 35$

The introductory narrative serves as an example to show that spaces of politics-from the space of the town council meeting to a national 38 assembly-are "performative articulations of power" (Gregson and 39 Rose 2000: 434). Spaces of politics and the political order inscribed 40 into them result from the iterative performances of political subjects 41 that define the "nature" of a hegemonic political order. In this case, 42 the colonial practice to hold town council meetings in Spanish has been 43 sedimented since colonial times, and, as a consequence, Spanish has 44 turned into the "natural" political language to speak in the spaces of 45 


\section{Carolin Schurr}

local politics in Chimborazo. The witnessed incident of kichwa speaking, however, exemplifies Butler's (1999) argument that within the reiterative citation of discursive practices, slippages are possible as there is no guarantee that a repetition (in this case the repetition of expressing demands to political authorities in Spanish) will be successful; its disciplines may fail. The discipline to speak in Spanish has failed because long-lasting social movement struggles and the introduction of the position of a rural town councilor in Ecuador's 2008 constitution have resulted in the election of the first indigenous town councilor in Riobamba. She called the political establishment into question by inviting the indigenous woman to speak in kichwa. Hence, focusing on the performative dimension of space provides opportunities to question how a hegemonic order becomes hegemonic and is challenged in a certain space (see Cream 1995: 39).

Indeed, Butler's concept of performativity is an inspiring source to think about the spatial materialization of hegemony and subversion and her "model of performativity has provided food for thought for many geographers" (Mahtani 2002: 427). It is therefore surprising that despite the growing interest in performativity in feminist and gender geographies (Bell et al. 1994; Bell and Valentine 1995; Nelson 1999; Longhurst 2000; Secor 2003; Pratt 2004), social and cultural geography (Malbon 1999; Nash 2000; Dewsbury 2000; Cloke et al. 2008), and economic geography (McDowell 2008, 2009), performativity "has not made many inroads within mainstream political geography" (Rose-Redwood 2008: 879). That being said, political geographers have employed performativity theory to examine the political genealogy of scales (Kaiser and Nikiforova 2008), political identities (Kuus 2007), questions of citizenship (Mahtani 2002; Baird 2006), borders (Strüver 2005), and political toponymies (Rose-Redwood, Chapter 7, this volume). While all of these accounts engage with the relation between performativity and the constitution of the political, the very spatialities of politics and the way these spatialities are (re-)produced or contested have been left unaddressed.

Inspirations to think about space in a performative way can be found in feminist geographies' early engagements with Butler's work. Focusing on the production of sexualized spaces, Bell et al. (1994) show that not only are performances of gender and sexuality located in space, they also sexualize space as homo- or heterosexual, straight, gay, lesbian, trans. They make the important point that there is no such thing as "a priori" heterosexual space-which is subverted by gays-showing that the apparently "natural" identity of space is the expression of a hegemonic order. Gregson and Rose further advance the notion of performative space by highlighting that not only the performers and their performances (of gender identity) are saturated with power, but 
also the spaces that are brought into being through these performances (Chapter 2, this volume). While Gregson and Rose have pushed Butler's argument further by arguing that spaces too need to be thought of as performative of power relations, their work gives few hints of how to conceptualize these power relations that are constitutive of performative political space.

To address this conceptual gap in Gregson and Rose's thinking, I bring Mouffe's (1993, 2005b) understanding of the political as antagonism/agonism into dialogue with the notion of performative space. While Mouffe's work complements the concept of performativity and performative space by focusing on the antagonistic struggle of collective identities, at the same time, performativity helps to address a shortcoming in Mouffe's elaboration of politics as antagonism. Even though Mouffe's politics of antagonism are based on theories of practice, she does not provide empirical evidence of how antagonism is brought into being through everyday political practices. The concept of performativity focuses attention on the everyday political practices that constitute the political spaces of antagonism. Hence, I suggest that Butler's work centering on performativity and Mouffe's work concerned with antagonism have much to say to each other and to a political geography of change. In fact, there is a major confluence between the work of Butler and Mouffe (and her co-author Laclau ${ }^{3}$ ) in general. Butler (1993: 146) has drawn on the concept of antagonism, e.g., in Bodies That Matter, to talk about the impossibility of a fixed subject position of "women." She has published a co-edited book with Ernesto Laclau on questions of universality and hegemony (Butler et al. 2000) and has engaged directly with Laclau and Mouffe's ideas of radical democracy in both her earlier (Butler 1993; Butler et al. 1997) and more recent work (Butler 2004a, 2004b, 2008, 2012). While (political) geographers have worked both with Mouffe/Laclau (Massey 1995; Natter 1995; Barnett 2004; Pugh 2005; 2007; Thien 2007) and Butler (see references discussed earlier), only few (Mattissek 2007, 2008; Müller 2008, 2009) have discussed the parallels between Mouffe/Laclau and Butler mainly with regard to their understanding of discourse (analysis). The next section discusses the parallels between Butler and Mouffe regarding their understanding of hegemony and power.

HEGEMONIC SPACES OF POLITICS

They [el pueblo] stigmatized me, first because I am a woman and, sec- 41 ond, for the color of my skin. For them, a mayor had to have blue 42 eyes, blond hair and a European stature. (interview with an indigenous 43 female mayor, August 2009) 44 


\section{Carolin Schurr}

Power often comes from claims concerning what is original, primordial, natural, inevitable, factual, genuine, real, scientific and the like, typically in a "founding" or "grounding" narrative of certainty. (Chambers and Carver 2008: 23)

The interview quote from an indigenous female mayor and the introductory ethnographic narrative empirically spell out what it means to think of power as performative in Butler's sense: the spaces of politics have been tightly circumscribed by masculinist, Eurocentric, and white ideals-be it with regard to the language spoken or the imaginaries of prototypical politicians. In the (post-)colonial spaces of politics in Ecuador, power has been established by declaring white-mestizo men as the natural political authority and through a grounding narrative of mestizaje, ${ }^{4}$ which has denied the indigenous history of the Ecuadorian state (Radcliffe and Westwood 1996). In the following, I revisit Butler's and Mouffe's understandings of performativity and hegemony with the aim to grasp the persisting and changing power relations that characterize Ecuador's political history.

I start with Butler's (2000: 14) acknowledgement that "the theory of performativity is not far from the theory of hegemony [...]: both emphasize the way in which the social world is made [...] through a collaborative relation with power." Butler highlights here the close relation between performativity and hegemony as both consider power central to any social and political organization. Mouffe (2005a: 17) agrees with Butler in this respect, considering "the concept of hegemony [as] the key notion for addressing the question of "the political." Before taking the notion of performativity "elsewhere"-namely to political geography-it is worth recalling Butler's notion of performativity. In the new preface for a second edition of Gender Trouble, Butler writes:

I originally took my clue on how to read the performativity of gender from Jacques Derrida's reading of Kafka's Before the Law. There the one who waits for the law, sits before the door of the law, attributes a certain force to the law for which one waits. The anticipation of an authoritative disclosure of meaning is the means by which that authority is attributed and installed: the anticipation conjures its object. [...] In the first instance, then, the performativity of gender revolves around this metalepsis, the way in which the anticipation of a gendered essence produces that which it posits as outside itself. Secondly, performativity is not a singular act, but a repetition and a ritual, which achieves its effects through its naturalization. (Butler 1999 [1990]: xv)

In this quote, Butler understands performativity as an expectation that ends up producing the very phenomenon that it anticipates. While Butler 


\section{Performativity and Antagonism 101}

has extensively shown what this expectation means for the way gender is sexually regulated, her reference to Kafka's (1998 [1925]) Before the $L a w$ is interesting when framing spaces of politics as performative. In Kafka's parable, the space of the Law is pictured as a room with a door. This place where the Law is supposed to exist is believed to be open for all, but is supposed to be guarded by a series of doors and doorkeepers. In liberal democracies, the "Law" is spatialized through the materialization of the law in institutions like the court. In a performative sense, however, the courthouse does not pre-exist the performance of judging and hearings. It is these performances that bring the space of the Law, the courthouse, into being. These spaces of the Law can be read as one example of spaces of politics, for spaces where politics are "done."

Hence, spaces of politics are performative in the same way as spaces of the Law as they are also brought into being by reiterative and citational practices that produce the effect that they name. Along with Kuus (2007: 91), who argues for refocusing research in political geography away from subjects of identity and toward the practices through which subjects are made, I call for the need to refocus on the citational practices that bring the spaces of politics into being. Performative spaces of politics do not emerge from a singular political act, but from a reiteration of norms that have assumed their political status through their repetition. Hence, spaces of politics can be re-figured as "imitations" (Butler 1993: 125) with no original. By thinking spaces of politics as iterative imitations with no original, the Eurocentrism of politics is pushed from its pedestal of providing the origin of political organization (see Campbell and Harbord 1999: 230 for the analogy to Butler's work). A performative approach to politics offers the possibility to trace the genealogy of politics, the history of the way spaces of politics were imagined and brought into being through discursive practices, without falling into the Eurocentric trap of considering the Greek polis-and more generally Western democracies-as the origin of politics and hence as a normative archetype. Hence, performativity offers the possibility to "de-naturalize" (Butler 1999 [1990]: xxi) or rather "de-colonize" the apparent "colonial" nature of spaces of politics.

The genealogy of the political has been traced in a de-naturalizing and de-colonizing way by Carole Pateman and Charles Mills in their respective books, The Sexual Contract (Pateman 1988) and The Racial Contract (Mills 1997), and in Contract and Domination (Pateman and Mills 2007). Their work is crucial when trying to understand spaces of politics as hegemonic institutions and to reveal their postcolonial history. Pateman writes in the opening of her book:

The most famous and influential political story of modern times is 42 found in the writing of the social contract theorists. The story tells 43 how a new civil society and a new form of political rights is created 44 


\section{Carolin Schurr}

through an original contract. An explanation for the binding authority of the state and civil law and for the legitimacy of modern civil government is to be found by treating our society as if it had originated in a contract. (Pateman 1988: 1)

Pateman and Mills critique contract theory as it has been developed by Thomas Hobbes, John Locke, Jean-Jacques Rousseau, Immanuel Kant, and John Rawls for missing half of the story which tells how specifically modern forms of patriarchy, racism, and imperialism are established. They show how imaginaries of the political inspired by classical contract theorists have justified the patriarchal, racial, and imperial structures that have shaped the political order and the very spaces of politics. ${ }^{5}$ Pateman (1988: 220-221) emphasizes that it was white men who sealed the original contract. Through this act, white women and nonwhites were performatively constructed as second-class citizens or not as citizens at all. White women and nonwhites were positioned outside the political and were denied access to the spaces of politics-just like the man from the country in Kafka's parable.

Hence, the spaces of politics are performatively brought into being through the juridical regimes of the racial and sexual contract. The racial and sexual contracts are examples of how in a performative analysis of the political "there is no power, construed as subject, that acts, but only [...] a reiterated acting that is power" (Butler 1993: 171). In this case acting consists of a reiterative citation of the contract. Hence, political spaces of contemporary democratic societies are produced by the recitative power of discourses of political (contract) theory that was employed to establish patriarchal and imperial (geo)politics.

\section{CONSTRUCTING HEGEMONIC SPACES OF POLITICS IN THE ANDES}

This political space I am occupying is a space from which women and especially Shuar women have always been excluded. (interview with an indigenous female national deputy of the Ecuadorian Asamblea Nacional, February 2008)

The way that spaces of politics are performatively brought into being through patriarchal and imperial imaginaries of the political can be traced and made visible by considering the practices of postcolonial democracy in Ecuador. The case of Ecuador-or the Andes more generally—highlights the power of Eurocentric and imperial discourses that served to normalize and naturalize white men as hegemonic political subjects even after formal independence. Both the cited interview quote and the colonial painting of three Spanish governors that still decorates the municipality in highland Chimborazo (Figure 4.1) mirror the (post)colonial imaginary of the political as white and masculine. 


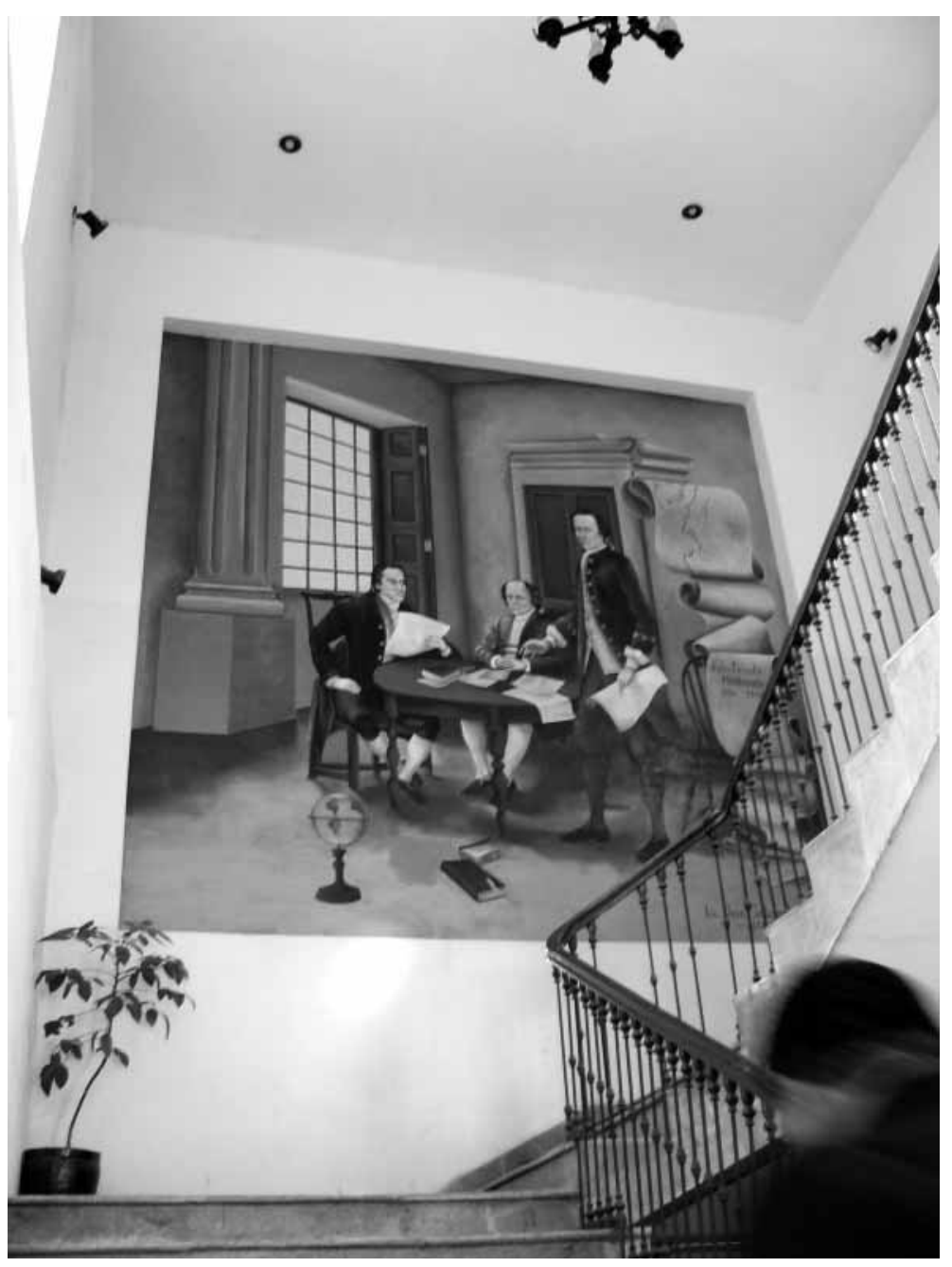

Figure 4.1 Colonial painting in the municipality of Riobamba, Chimborazo.

With the Spanish conquest a new world appeared on the horizon of 36 European imaginaries, being considered as "the tabula rasa on which 37 the principles and accomplishments of Western rationality (religious 38 beliefs, scientific advances, and humanistic paradigms [including politi- 39 cal order]) could and should be inscribed" (Moraña et al. 2008: 7). The 40 white men's superiority was naturalized by dividing the colonial politi- 41 cal order into two parallel "republics" (the República de los españoles 42 and the República de inidos), relegating indigenous people outside the 43 colonial spaces of politics. Furthermore, heterosexuality and "gender 44 relations have provided a template for the organization of relations of 45 


\section{Carolin Schurr}

power and difference" (Radcliffe 2000: 172). Marital laws, property laws, and land laws gendered the political architecture of imperialism (McClintock 1995) in a way that women-white, indigenous, and Creole women to different extents-were positioned by these juridical regimes outside, or in Kafka's word "before," the spaces of politics as the colonial regime denied them access to political participation and citizenship. The colonial marking of spaces of politics as white and masculine can be seen as a result of citational practices like the indigenous tribute (a tax demanded by the church and the state) and the constant effort to (re)produce the gendered and racialized political ideas, routines, and practices from the metropolis in the colonies. As the performances do not outlast the moment of their acting, the colonizing acts had to be repeated permanently in order to reassert the (post)colonial gendered and racialized order. Both gendered and racialized power dynamics were from the outset fundamental to the securing and maintenance of colonial discourse and also determined the constitution of politics in postcolonial times. With independence from Spain, liberal ideals based on contract theory were (re)produced to legitimate the privileges of Creoles (American-born whites), while at the same time "retaining aspects of Spanish colonial legislation and institutions ensured the continued subjugation of Indians" (Clark and Becker 2007: 8). The power of the colonial juridical regimes becomes visible in the reproduction of colonial racialized and gendered structures after the termination of Spanish rule, e.g., in the perpetuation of the indigenous tribute (Prieto 2004) or the denial of suffrage for women, illiterates, and people without property (Dore and Molyneux 2000; Radcliffe 2002; Prieto and Goetschel 2008). The effects of the colonial logic of ordering and organizing spaces of politics still reverberate in the form of the colonial architecture of municipalities and imaginaries of authority (see Figure 4.1 and the quote from mayor Mantilla earlier) as well as political rituals and procedures (like the routine of a town council meeting).

Through these kinds of practices and imaginaries the hegemonic "nature" of (post)colonial order along gendered and ethnic cleavages was brought into being and is constantly (re)produced up to the present. To trace the history of Ecuadorian politics, therefore, requires that we recognize "the hegemonic nature of every kind of social order and the fact that every society is the product of a series of practices attempting to establish order in a context of contingency" (Mouffe 2005a: 17). According to Mouffe (2005a: 18), every (political) order is a temporary and precarious articulation of contingent practices- “things could always be otherwise." The fact that any hegemonic order is based on some form of exclusion-in the case of the Andes, the exclusion of the indigenous, mestiza, Afro-descendants, and women-means that "there are always other possibilities that have been repressed and that can be reactivated" (Mouffe 2005a: 18). In short, the colonial order was constantly under threat of being challenged by counter- 
hegemonic practices of excluded populations, "practices which attempt to disarticulate the existing order so as to install another form of hegemony" (2005a: 18). The next section brings together Mouffe's thinking about the contingency of the political order with Butler's endeavor to think about the way that subversive- or counter-hegemonic-practices institute "new modes of reality" (Butler 2004b: 217).

\section{CONTESTING HEGEMONY}

The political arises when the given order of things is questioned; when

Mouffe and Butler are interested in questions of how social change occurs $\quad 16$ within and despite of a hegemonic order. They both embrace a poststruc- 17 turalist epistemology that denies any pre-discursive essence. Hegemonic 18 orders-be it a gender or a democratic order-are never stable in their $\quad 19$ view because of the ambiguity and contingency in any discursive formation 20 of identity or spatiality. The way that they picture political change, how- 21 ever, differs slightly. While both Mouffe and Butler assume that political 22 change occurs when hegemonic power relations are challenged by counter- $\quad 23$ hegemonic practices (Butler 1997: 160; Mouffe 2005a: 33), Butler speaks 24 of subversion and slippage, whereas Mouffe refers to processes of disartic- 25 ulation-rearticulation that constitute an antagonistic politics. In my view, 26 the main difference between their approaches is the type of political agency 27 inscribed in the concepts of subversion and antagonism, respectively. 28

For Mouffe (2005a: 19; 2005b: 12;), one of the main tasks of democratic 29 politics consists of defusing the potential antagonism between collective 30 political identities of "we/they" that exists in any political order. In Hege- 31 mony and Socialist Strategy, Laclau and Mouffe (1985: 170-171) high- 32 light the importance of collective political identities such as the "new social 33 movements" for an antagonistic politics. They emphasize, however, that 34 these collective identities are constructed and hence are subject to an always 35 fluid and instable character along floating demarcating lines. In contrast, 36 Butler's call for "repetitious citation of subversive interventions rejects the 37 traditional model of mass politics" (Chambers and Carver 2008: 46). 38

Butler does not put forward a theory of subversion and provides little 39 explicit conceptualization of the term. She argues that the norms that gov- 40 ern what is (not) real and who is intelligible as a (political) subject are called 41 into question and reiterated at the moment in which performativity begins 42 its citational practice (see Butler 2004a, 2009 on this point). In other words, 43 because a citational performance needs to be reiterative to reproduce its 44 effect, slippage is not only possible but also inherent to the very process of 45 


\section{Carolin Schurr}

reiteration. Therefore, "it is in the slippage inherent to discourse, that both intentional and unintentional change occurs" (Haller 2003: 763). Although Butler rejects models of mass politics, her conceptualization of performativity as sedimented practices requires not only a single act of resistance, but the reiteration of these acts. The constant repetition of subversive acts-like drag-is necessary to destabilize apparently "natural" or "hegemonic"gender or political-orders. In fact, Butler's aim to destabilize the power through which the troubling norm(ality) of gender is naturalized is not far from Mouffe's assumption that any hegemonic order is susceptible to being challenged by counter-hegemonic practices.

For Mouffe (2005a: 33), it is agonistic struggle that "should bring new meanings" through "a process of disarticulation of existing practices and creation of new discourses and institutions." Drawing on Gramsci's notion of disarticulation, Mouffe (1979: 193-194) locates transformation within the political struggles between two hegemonic principles to appropriate ideological elements in a process of disarticulation-rearticulation of given ideological elements. Emphasizing the "composite, heterogeneous, open and ultimately indeterminate character of democratic tradition" (Mouffe 1993: 17), she maintains that because a political order at a given moment is the result of relations of forces, it is the object of a perpetual process of transformation. In other words, transformation can be realized because a hegemonic order is only a precarious articulation of contingent practices that is always already contested through the possibility that things could be otherwise or, more precisely, that a political order could be imagined and later on rearticulated in a different way.

Laclau has focused on the transformative potential of social movements, arguing that political change occurs when counter-hegemonic subjects articulate their "demands." Any hegemonic order consists of a confrontation between unfulfilled demands, on the one hand, and an unresponsive power, on the other hand (Laclau 2005: 86). At the beginning, the series of isolated demands articulated by diverse movements have nothing in common but demanding something from the political order and authorities. The only common characteristic of these diverse demands is the fact that they are opposed to the hegemonic system that they consider as lacking, repressive, or menacing. It is the experience of lack, repression, and menace that first leads to general frustration of a series of social demands before it facilitates the movement from isolated democratic demands of particular movements to more popular ones, articulated in a collective counter-hegemonic subjectivity.

\section{PERFORMING ANTAGONISM IN CHIMBORAZO'S LOCAL POLITICS}

While the introductory ethnographic narrative suggests that indigenous people have only recently entered the arena of institutionalized politics in Chimborazo, the province has a long history of indigenous resistance. 


\section{Performativity and Antagonism 107}

Indigenous people in Chimborazo were among the first to question the hegemonic (post)colonial order in Ecuador, when in 1871 they protested against the indigenous tribute (Clark and Becker 2007: 11). From then on, indigenous people fought against the state, demanding more autonomy, less economic and social exploitation, and land reforms. Their "demands" (Laclau 2005) were clearly opposed to the hegemonic system they experienced as repressive and menacing. In 1974, Lázaro Condo, an indigenous protester, died in the midst of a confused confrontation between the police and indigenous members of the comuna Tocetzinín in Chimborazo who occupied a disputed plot of land. Becker (2008: 144) states that his assassination coincided with "a shift in the content, discourse, and strategies of indigenous movements." This shift consists in Laclau's terms of a collectivization of particular demands as the indigenous protest against the hegemonic order was increasingly joined by civil rights, students, women's, and popular movements that questioned the status quo. It is the increasing collective opposition of these different movements that results in a new political configuration. This new configuration triggers "change in Indian ethnic identification" (Crespi 1981: 478) and their relations with the whitened spaces of politics.

The increasing antagonism between the white-mestizo state and indigenous movements culminated in 1990 in a nationwide levantamiento (uprising) consisting of massive blockades that shut down the country for a week (Menacho 1991; Whitten et al. 1997). The political space of the indigenous uprising was brought into being through mass mobilizations citing popular forms of protests in Latin America. The protests transformed streets and plazas into political spaces through the presence of their counter-hegemonic bodies and demands toward the state. The protests forced the government to negotiate their demands. In the negotiations, the boundary between the counter-hegemonic political spaces and the hegemonic spaces of politics was blurred. To speak in Kafka's words, the (indigenous) man from the country was permitted access to the hegemonic spaces of politics-in this case the edifice of the National Congress. The clear-cut boundary between indigenized political spaces and white-mestizo spaces of politics became even fuzzier, when in 1996 the indigenous and peasant party Pachakutik was founded and indigenous movement politics became institutionalized within the very spaces of politics.

The provincial council of Chimborazo and the municipality of Riobamba serve as useful examples to consider the ways in which spaces of politics have (not) been transformed since the indigenous uprisings. As the introductory ethnographic narrative has shown, only few signs of political transformation are visible in Riobamba. The colonial building of the municipality is decorated with colonial paintings (see Figure 4.1), the mayor is a white-mestizo man, and few indigenous people can be spotted within the municipality. Since the last election, however, one indigenous woman holds a seat in the town council; she was the one that the kichwa-speaking woman addressed 


\section{Carolin Schurr}

in her speech. The fact that an indigenous town councilor was present needs to be seen as an effect of the performative politics of language (Butler 1997). Thanks to indigenous pressure in the constitutional negotiation a new political representative was introduced at the municipality level: the rural town councilor. While this function seems a paradox in itself, it is the colonial ordering of political territoriality that explains this position. The rural town councilor is elected by the-mainly indigenous-rural communities that are part of the municipality's territory. As the rural areas have been (post)colonially neglected by-mainly mestizo-politicians and their political actions, the establishment of rural town councilors in 2008 can be viewed as a result of the demands of the indigenous movement for political representation. Hence, the incidence of the first kichwa dialogue in the town council shows the material effects produced by performative utterances inscribed in the constitution. Shifts in the political language toward de-colonization, including a better representational system of rural areas, produce a de-colonized space of politics, in which an indigenous woman is for the first time able to speak in her mother tongue.

While processes of de-colonization are just starting to unfurl in the municipality of Riobamba, the de-colonizing effects of the indigenous party Pachakutik are more visible in Chimborazo's more rural municipalities, where indigenous people outnumber the mestizo population. In fact, the municipality of Guamote was among the first municipalities in Ecuador to be headed by an indigenous mayor. Mariano Curicama's election as mayor in 1991-concurrent with the election of two indigenous town councilorsreflected a rapid shift in political power away from the traditional, whitemestizo feudal elite. Mestizo elites responded by trying to prevent Curicama from taking office. In return, indigenous organizations threatened to boycott mestizo businesses. This threat cleared his path, together with the accompaniment of 5,000 indigenous supporters, who literally stood behind him as he entered the building of the municipality (Van Cott 2008: 155). This incident shows not only the forceful antagonism that often accompanies processes of change, but the centrality of spatial appropriation. In order to "become" mayor, Curicama had to enter the building of the municipality. It was through the bodily appropriation of the municipality that he actually challenged the hegemonic spatial order of politics. The sheer presence of bodies that are racialized as "indigenous" through colonial discourses within spaces of politics that have been marked as white for centuries destabilizes the hegemony of the (post)colonial political order. The sedimentation of counter-hegemonic practices such as protests, political organization of indigenous communities, and forming of alliances finally resulted in the contestation of the hegemonic (post)colonial political order. Through the iteration of these subversive practices, the norms dictating that indigenous people are not intelligible political subjects were directly challenged.

Nowadays, Curicama is - in the second term-the head of the province of Chimborazo, the prefect. It is not only the presence of his racialized body, 


\section{Performativity and Antagonism 109}

and that of many indigenous people who wait to be attended by Curicama, that indigenizes and thus de-colonizes the spaces of the provincial council in Riobamba, but the bilingual signage in Spanish and kichwa within the building that helps citizens to find their way around, the indigenous wipala flag that decorates the floors of the building, and the announcement of a number of activities like the invitation for an assembly to define participatory budgets or a song contest for indigenous women's groups on International Women's Day that traditionally had not taken place within the building of the provincial council. The appropriation of this formerly (post) colonial white-mestizo space of politics takes place through re-signifying a new meaning of the spatiality to which indigenous people frequently had been denied access during (post)colonial times. Additionally, the frequent visits of Curicama in the rural indigenous communities temporarily erect spaces of politics in the country, decentering the urban monopoly as a site for institutionalized politics.

From this evidence, one could assume that the antagonistic struggle between hegemonic (white-mestizo) subjectivities and counter-hegemonic (indigenous) subjectivities and imaginaries of political order has resulted-at least in the provincial council in Chimborazo-in an initiating process of de-colonization. It seems that a new, more inclusionary, pluralist democracy has been established that includes formerly excluded social groups. As Radcliffe et al. (2002: 299) highlight, however, "alongside the expansion of political opportunity lie exclusionary patterns of political culture that limit participation." While the antagonistic struggle of the indigenous movement against the white-mestizo political elites permitted the insertion of indigenous citizens into spaces of politics, new antagonisms and exclusions persist in making that access unequal and/or denying the access at all to certain members of subaltern groups. In the province of Chimborazo, for example, the gendered political culture of indigenous organizations and the "cultural constructions of non-authoritative and apolitical femininity" (Radcliffe et al. 2002: 300) still position women at the margin of spaces of politics just like the man from the country in Kafka's parable. By doing so, indigenous political orders (re)produce the apparently "natural" masculinity of spaces of politics, as the statement by one of the few female indigenous politicians in Chimborazo evidences:

It is that ... always politics, all the life, politics has always been done by men-everything-be it organizations of the (indigenous) comunidades, (...) be it in the political parties, even in Pachakutik everything is ruled by men. (interview with an indigenous female rural town councilor, March 2010) 


\section{Carolin Schurr}

workshops that aim to organize, train, and inform the women about their political rights. These activities are quite successful as the following quote demonstrates:

Before [the gender quota law], we did not know anything, they [the men] told us to vote for someone and we all voted for this person. Sure, there have always been a few women, but we, the women themselves, didn't vote for the female candidates, because we believed that men are the only ones who can do politics. (interview with an indigenous female rural town councilor, April 2009)

Despite the gender quota law, introduced in 1998, only few female candidates have actually been elected into office in Chimborazo (CONAMU 2009). Indigenous women with long-standing experience in "informal" politics have nevertheless begun to question the masculine hegemony inherent in indigenous spaces of politics. Thus, a new antagonism is emerging between indigenous women and indigenous politicians like Curicama who, in the meantime, have turned into hegemonic political subjects-at least in the province of Chimborazo.

This empirical case study highlights how antagonisms are spatially materialized. The "spatial contradictions" (Lefebvre 1991: 365), e.g., that between the indigenized space of the provincial council and the mestizo space of the municipality, are a result of and at the same time express the particular power relations that saturate the province of Chimborazo. Whereas the municipality is constituted by the hegemony of mestizo political subjectivities and practices, in the provincial council former counterhegemonic subjects have turned into hegemonic subjects that define the political order and agendas. Both spaces are highly exclusionary as indigenous people have very little voice in the municipality and mestizo people feel neglected by the policies of Curicama whose "participative" budgets mostly benefit indigenous communities (personal communication with a functionary of the provincial council, March 20, 2010).

Following the antagonistic logic of resistance studies (Rose 2002; Sharp et al. 2000) that aim to highlight how hegemonic spaces of politics are subverted, appropriated, and contested, the story could end at this point, as it has been shown how the (post)colonial white-mesitzo "nature" of spaces of politics has been successfully challenged through social movement protest and how spaces of politics have been appropriated by counter-hegemonic subjects. Along with Mouffe, however, I would like to go one step further by asking how the kind of spatial antagonism encountered in the province of Chimborazo could be transformed into agonism with the aim to facilitate a pluralist democracy. In other words, how could antagonistic struggles be "tamed thanks to the establishment of institutions and practices through which the potential of antagonism can be played out in an agonistic way" (Mouffe 2005a: 20-21)? 


\section{OPEN UP POSSIBILITIES? THE UTOPIA OF AGONISM}

What resources must we have in order to bring into the human community those humans who have not been considered part of the recognizably human? That is the task of a radical democratic theory and practice that seeks to extend the norms that sustain viable life to previously disenfranchised communities. (Butler 2004b: 225)

Coming to terms with the hegemonic nature of social relations and identities, it [an agonistic approach] can contribute to subverting the ever-present temptation existing in democratic societies to naturalize its frontiers and essentialize its identities. (Mouffe 2005a: 105)

In the previous sections, I have outlined how a performative approach to spaces of politics reveals the power relations and related effects of naturalization of a hegemonic order that constitute the spatialities of politics. The concept of performative space certainly is a helpful tool for a critical political geography to conceptualize processes of hegemonization (Mouffe), naturalization (Butler), counter-hegemonization (Mouffe), and subversion (Butler) that bring the spatialities of politics into being. In the the remainder of this chapter, however, I argue that in order to fully realize the potential of Butler's work for political geography, it is crucial to draw on her more recent writings in which she engages more directly with questions of social transformation, norms, politics, and democracy (Butler 2004a, 2004b, 2009; Butler and Spivak 2007; Butler 2012). As it is impossible to engage with the whole of her later work, I will focus on some arguments that Butler makes in Undoing Gender (2004b). Butler's recent work does not focus on performativity as explicitly as her earlier work. As a tool to denaturalize established norms, performativity remains crucial, yet she insists that we must "expand our fundamental categories" to make them "more inclusive and responsive to the full range of cultural populations" (Butler 2004b: 223). It is in the chapter, "The Question of Social Transformation," that Butler links this call to the theory of radical democracy as it was outlined by Mouffe and Laclau (1985). She considers the extension of norms that "sustain viable life to previously disenfranchised communities" as a central "task of a radical democratic theory and practice" (Butler 2004b: 225). In doing so, Butler emphasizes that norms define the intelligibility of a (political) subject and that as long as someone is not recognized as intelligible, one cannot enter into an antagonistic-or even oppressed-relation with the hegemonic subjects. Mouffe, by contrast, does not pay attention to the question of (un)intelligibility but departs from the assumption that the political is constituted by an antagonistic relation between intelligible subjects who are identifying with binary collective identities of us/them. For her, the most important challenge for contemporary democracies consists in establishing "this us/them discrimination in a way that is compatible 


\section{Carolin Schurr}

with pluralist democracy" (Mouffe 2005b: 101). Butler and Mouffe come together in their search to "generate new possibilities" (Butler 2004b: 194) of conviviality within a pluralist democracy, although they suggest different modes to achieve this goal: the expansion of the norms of intelligibility (Butler) and the transformation from antagonism into agonism (Mouffe). In other words, both scholars are centrally concerned with thinking through a way to create a social and political order that embraces difference, challenges norms (and practices of disciplinary normalization), and overcomes mechanisms of exclusion, violence, and oppression.

While Butler (2004b: 225) advocates a process of cultural translation to achieve this aim, Mouffe (2005a: 20-21; 2005b: 98-105) proposes an agonistic model of democracy, which channels dissenting voices in a nonviolent way. For Mouffe, the aim of democratic politics is to transform antagonistic relations between enemies into an agonistic relationship in which the conflicting parties recognize the legitimacy of their adversary. Because they are adversaries and not enemies, "they see themselves as belonging to the same political association, as sharing a common symbolic space within which the conflict takes place" (Mouffe 2005a: 20). Mouffe's model recognizes that any society is structured around the agonistic configuration of power relations "between opposing hegemonic projects which can never be reconciled rationally" (Mouffe 2005a: 21). It is the task of a pluralist democracy to create a set of democratic institutions and procedures that regulate these agonistic confrontations between adversaries.

\section{INTERCULTURALIDAD—AN EXAMPLE FOR AGONISTIC POLITICS?}

Mouffe does not spell out empirically what kinds of ideologies, institutions, and everyday practices are able to channel dissenting voices in a radical democracy. In the following, I would like to consider the extent to which the concept of interculturalidad that was introduced to Ecuador's constitution in 1998 could be seen as a political utopia in Mouffe's sense of agonism. The concept of performativity serves once again as a crucial tool to grasp the processes of spatial materialization that challenge the white-mestizo hegemony by imagining and performing spaces of politics as intercultural. Interculturalidad as a concept-in a similar way as agonism-departs from the configuration of power relations around which a society-in this case the postcolonial society of Ecuador-is structured (in contrast to multiculturalism that seeks to harmonize conflictive relations between different groups). The conflict that results from the historical power relations between hegemonic and counter-hegemonic groups in a postcolonial society is inherent in and made visible through the concept of interculturalidad, as it recognizes the existence of divergent epistemologies, ideologies, and interests. Walsh (2003: 112) highlights that interculturalidad is understood as both a process and project to confront and transform 
power relations and the hegemony of political institutions that excludes certain social groups. One could say that interculturalidad is the postcolonial version of agonism as it "proposes a model of political organization for decolonization aimed at recovering, strengthening and democratizing the state $[. .$.$] , transforming the structures and institutions in order to recog-$ nize political and cultural diversity" (Walsh 2009: 78).

Since the 1990s, interculturalidad has been a crucial demand by both indigenous and Afro-Ecuadorian movements that was first addressed by the state in the 1998 Constituent Assembly (Walsh 2008b: 507). Through a performative speech act, Ecuador was declared a "plurinational and multiethnic state" (Art. 1) by the constitution of 1998. The constitution of 2008 slightly altered the speech act when stating in its first article that "Ecuador is an intercultural and plurinational state." The sedimentation of these speech acts has been realized through their iterative citation in political speeches, political agendas, and academia. The ongoing transformation of the political order toward an intercultural space of politics, however, has not only taken place through a discursive reframing but also through everyday practices. The presence of indigenous and Afro-Ecuadorian people in important political positions, their declaration as nationalities, and their cosmologies (e.g., the concept of sumak kawsay, an indigenous philosophy of "living well"-for more details see Radcliffe 2012) challenged the uninational and mono-cultural framework of Ecuador's postcolonial democracy. Especially in local spaces of politics, serious attempts have been made to translate the discourse of interculturalidad into political practices by creating intercultural round tables (mesas interculturales), introducing participatory budgeting processes that take into account the divergent interests and necessities of different social groups, and realizing workshops and discussions around alternative visions of (local) development and participation. These politically progressive initiatives aim to rethink and refound spaces of politics interculturally by encouraging "politics of convergence, of conviviality" (Walsh 2009: 71) between ideologically, epistemologically, and ethnically different collective identities.

These intercultural practices and spaces challenge the postcolonial white-mestizo hegemony that has dominated spaces of politics. Intercultural imaginaries propose a mode of political order that recognizes differences in ideologies and provide a space for democracy in the form of the intercultural round table where agonistic struggle between different groups can literally take place. While these spaces exist and the discourse of interculturalidad has gained importance within the discursive political field of Ecuador, a critical evaluation of intercultural spaces of politics shows that new forms of antagonism rather than agonism constitute these spaces. Lalander (2010: 506) refers to the antagonism resulting from intercultural politics as an "intercultural dilemma." It emerges when an indigenous or Afro-Ecuadorian mayor starts providing welfare for all social sectors, without prioritizing indigenous or Afro-Ecuadorian grievances. 


\section{Carolin Schurr}

The protests of these social groups certainly need to be seen as a reflection of centuries of exclusion and frustrated expectations, but to refound spaces of politics interculturally would demand to respect the mestizo population as legitimate adversaries with whom an agonistic confrontation is possible over the distribution of resources. Hence, the political reality evidences that "interculturalidad still does not exist, but is a project to be constructed" (Walsh 2008a: 140). With this permanent lack, interculturalidad presents an example of a social imaginary or horizon as discussed by Laclau (1990: 64), that is, a constant social demand that, due to the dialectical relation between hegemony and lack, can never be fully achieved.

Interculturalidad can be considered a political project and practice in postcolonial societies that could actually facilitate an agonistic radical democracy. Intercultural spaces of politics can therefore be imagined as spaces that include marginalized, oppressed, and unintelligible subjects; provide room for dialogue between different ideologies and epistemologies; and overcome exclusionary and antagonistic modes of political order. These de-colonized, intercultural spaces of politics could be seen as a response to Butler's (2004b) call to "increase the possibilities for a livable life for those who live on the [...] margins" by guaranteeing the marginalized subjects access to the very spatiality of politics as political intelligible subjects. Through the performative expansion of the norms that constituted the spaces of politics of an agonistic and intercultural radical democracy, the door of the law would be literally opened to the man (and woman) from the country in Kafka's parable.

\section{CONCLUSION}

In order to make the notion of performative space productive for political geography, I have argued that we need to engage further with the performative articulations of power (relations) that constitute the spaces of politics. I have suggested that to be able to embed the notion of performative space within the context of politics, closer attention needs to be paid to the conceptualization of the processes of (counter-)hegemonization that define or contest a spatial political order through their citational, sedimented practices. Framing power in antagonistic terms, the concept of performative space gains potential for a critical political geography in three main aspects: first, recognizing that the "political is linked to the acts of hegemonic institutions" (Mouffe 2005a: 17), the (historical) citational practices-like contract theory, colonial tributes, laws, and architecturethat have established a hegemonic political order can be de-naturalized and de-colonized with the Butlerian tool of performativity. Second, employing the concepts of subversion (Butler) and disarticulation (Mouffe), it can be shown how hegemonic orders are contested through slippages in the reiteration of citational practices - on the level of the subject—and through the 
articulation of collective demands and alternative imaginaries. By bringing these two theoretical tools together, not only can a bridge be built between collective and individual forms of resistance, but the relationship between social structures and agency can also be reframed. The empirical analysis of counter-hegemonic struggles of indigenous movements in Ecuador highlighted how change is materialized in more inclusionary spaces of politicsthrough slippages in the citational practices like a kichwa speech in a (post) colonial, white-mestizo space of politics and through the collectivization of demands such as the call for suffrage. Third, Mouffe and Butler both search for alternative, more inclusionary modes of social and political conviviality. I propose that the political utopia of interculturalidad as incorporated in the Ecuadorian constitution can be considered as a political imaginary that both responds to Mouffe's call for an agonistic democracy and Butler's demand to expand the norms of (political) intelligibility. A critical political geography therefore should be located between the need to look back at the genealogies of spaces of politics through a performative lens in order to denaturalize and de-colonize the hegemonic "nature" of exclusionary spaces of politics and the desire to think political horizons such as interculturalidad as agonistic imaginaries of a pluralist democracy.

First of all, I would like to thank the politicians of the Province of ChimThanks to the editors Michael Glass and Reuben Rose-Redwood who have invited me to contribute to this edited collection and have kept supporting me along the way in crafting this chapter. Martin Müller, Katharina Abdo, Juliet Fall, and Bettina Fredrich, as well as two anonymous reviewers, have helped me to sharpen the central argument of this chapter, and I am very grateful for their thoughtful comments. This research was supported by funding from the Swiss National Science Foundation (SNF).

1. This chapter is based on fieldwork conducted in the province of Chimborazo between 2008 and 2010 for a broader research project that was interested in how gender and ethnicity intersect in the spaces of local politics in Ecuador. It examined the effects of the gender quota law and the foundation of indigenous parties on the participation of women and ethnic minorities in local politics. To this end, long-term ethnography was realized in the Provinces of Chimborazo, Orellana, and Esmeraldas where interviews were conducted with local politics and representatives of women's and ethnic movements. This chapter focuses exclusively on empirical data from the Province of Chimborazo as the colonial traces are most evident in this highland province 


\section{Carolin Schurr}

and antagonisms between indigenous and mestizo imaginaries of politics are more visible than in other provinces.

2. Feminist political geographers have called for the need to take into account diverse political spaces beyond institutionalized politics (Staeheli 1996; Brown and Staeheli 2003; England 2003; Kofman 2008). In their endeavor to open up the narrow, masculinist, and state-centered perspective of mainstream political geography, they have neglected institutionalized politics and their respective spaces of politics. In this chapter, I refocus attention on the spaces of politics. As spaces of electoral politics mirror the power relations inherent in society, I consider the study of institutionalized politics as a possibility to trace both the genealogies of these power relations that constitute spaces of politics and the contestation of these power structures.

3. Mouffe's work is often closely associated with the work of Ernesto Laclau as they co-authored Hegemony and Socialist Strategy (1985). While I do draw on this earlier work of Mouffe that she elaborated jointly with Ernesto Laclau, I concentrate in this chapter on her later-single authored-work that engages more profoundly with the question how an agonistic pluralism can be established as political order.

4. Mestizaje celebrated racial and cultural mixtures as a way of forging a unified and homogeneous national image at the same time that it reasserted the supremacy of the European race and civilization by favoring blanqueamiento or whitening (Safa 2005: 307).

5. It is important to highlight that Pateman and Mills discuss the similarities and differences between gender and race. While they consider "masculinity," "femininity," and "race" as political constructs that result from the language of nature employed in contract theory, they argue that gender (for the division between childbearing and non-childbearing halves of humankind) has a much longer history than race, which only comes into existence in the modern period (Pateman and Mills 2007: 5).

\section{REFERENCES}

Baird, B. (2006). Sexual citizenship in "the New Tasmania." Political Geography, 25(8), 964-987.

Barnett, C. (2004). Deconstructing radical democracy: articulation, representation, and being-with-others. Political Geography, 23(5), 503-528.

Barnett, C. and Low, M. (2004). Geography and democracy: an introduction. In C. Barnett and M. Low (Eds.), Spaces of democracy: Geographical perspectives on citizenship, participation and representation (pp. 1-22). London: Sage Publications.

Becker, M. (2008). Indians and leftists in the making of Ecuador's modern indigenous movements. Durham: Duke University Press.

Bell, D., Binnie, J., Cream, J., and Valentine, G. (1994). All hyped up and no place to go. Gender, Place \& Culture, 1(1), 31-47.

Bell, D. and Valentine, G. (1995). Mapping desire: Geographies of sexuality. London: Routledge.

Brown, M. and Staeheli, L. (2003). "Are we there yet?" Feminist political geographies. Gender, Place and Culture, 10(3), 247-255.

Butler, J. (1993). Bodies that matter: On the discursive limits of "sex." New York: Routledge.

. (1997). Excitable speech. A politics of the performative. New York: Routledge. 


\section{Performativity and Antagonism 117}

. (1999 [1990]). Gender trouble: Feminism and the subversion of identity (2nd ed.). New York: Routledge.

. (2000). Restaging the universal: hegemony and the limits of formalism. In J. Butler, E. Laclau, and S. Zizek (Eds.), Contingency, hegemony, universality: Contemporary dialogues on the Left (pp. 11-33). London: Verso.

- (2004a). Precarious life: The powers of mourning and violence. London: Verso.

- (2004b). Undoing gender. New York: Routledge.

. (2008). Sexual politics, torture, and secular time. The British Journal of Sociology, 59(1), 1-23.

- (2009). Frames of war: When is life grievable? London: Verso.

. (2012). Parting ways: Jewishness and the critique of Zionism. New York: Columbia University Press.

Butler, J., Laclau, E., and Laddaga, R. (1997). The uses of equality. Diacritics, 27(1), 3-12.

Butler, J., Laclau, E., and Zizek, S. (2000). Contingency, hegemony, universality: Contemporary dialogues on the left (pp. 11-33). London: Verso.

Butler, J. and Spivak, G.C. (2007). Who sings the nation-state? Language, politics, belonging. Oxford: Seagull Books.

Campbell, J. and Harbord, J. (1999). Playing it again. Theory, Culture \& Society, 16(2), 229-239.

Chambers, S. and Carver, T. (2008). Judith Butler and political theory: Troubling politics. New York: Routledge.

Clark, K. and Becker, M. (2007). Indigenous peoples and State formation in modern Ecuador. In K. Clark and M. Becker (Eds.), Highland Indians and the state in modern Ecuador (pp. 1-21). Pittsburgh, PA: University of Pittsburgh Press.

Cloke, P., May, J., and Johnsen, S. (2008). Performativity and affect in the homeless city. Environment and Planning D: Society and Space, 26(2), 241-263.

CONAMU. (2009). Las mujeres en el proceso electoral 2009. Unpublished report, Quito.

Cream, J. (1995). Re-solving riddles: the sexed body. In D. Bell and G. Valentine (Eds.), Mapping desire (pp. 31-40). London: Routledge.

Crespi, M. (1981). St. John the Baptist: the ritual looking glass of hacienda ethnic and power relations. In N. Whitten (Ed.), Cultural transformations and ethnicity in modern Ecuador (pp. 477-505). Chicago: University Press of Illinois Press.

Dewsbury, J.D. (2000). Performativity and the event: enacting a philosophy of difference. Environment and Planning D: Society and Space, 18(4), 473-496.

Dore, E. and Molyneux, M. (2000). Hidden histories of gender and the State in Latin America. Durham, NC: Duke University Press.

England, K. (2003). Towards a feminist political geography? Political Geography, 22(6), 611-616.

Gregson, N. and Rose, G. (2000). Taking Butler elsewhere: performativities, spatialities and subjectivities. Environment and Planning D: Society and Space, 18(4), 433-452.

Haller, A. (2003). Art of the demolition derby: gender, space, and antiproduction. Environment and Planning D: Society and Space, 21(6), 761-780.

Kafka, F. (1998 [1925]). Der Prozess. Reclam, Stuttgart.

Kaiser, R. and Nikiforova, E. (2008). The performativity of scale: the social construction of scale effects in Narva, Estonia. Environment and Planning D: Society and Space, 26(3), 537-562.

Kofman, E. (2008). Feminist transformations of political geography. In K. Cox, M. Low, J. Robinson (Eds.), The SAGE handbook of political geography (pp. 73-86). London: SAGE Publications. 


\section{Carolin Schurr}

Kuus, M. (2007). Ubiquitous identities and elusive subjects: puzzles from Central Europe. Transactions of the Institute of British Geographers, 32(1), 90-101.

Laclau, E. (1990). New reflections on the revolution of our time. London: Verso.

. (2005). On populist reason. London: Verso.

Laclau, E. and Mouffe, C. (1985). Hegemony and socialist strategy: Towards a radical democratic politics. London: Verso.

Lalander, R. (2010). Between interculturalism and ethnocentrism: local government and the indigenous movement in Otavalo-Ecuador. Bulletin of Latin American Research, 29(4), 505-521.

Lefebvre, H. (1991). The production of space. Oxford: Blackwell.

Longhurst, R. (2000). "Corporeographies” of pregnancy: "bikini babes.” Environment and Planning D: Society and Space, 18(4), 453-472.

Mahtani, M. (2002). Tricking the border guards: performing race. Environment and Planning D: Society and Space, 20(4), 425-440.

Malbon, B. (1999). Clubbing. Dancing, ecstasy and vitality. London: Routledge.

Massey, D. (1995). Thinking radical democracy spatially. Environment and Planning D: Society and Space, 13(3), 283-288.

Mattissek, A. (2007). Diskursanalyse in der Humangeographie. "State of the art." Geographische Zeitschrift, 95(1-2), 37-55.

-. (2008). Die neoliberale Stadt: Diskursive Repräsentationen im Stadtmarketing deutscher Grossstädte. Transcript, Bielefeld.

McClintock, A. (1995). Imperial leather. Race, gender and sexuality in the colonial contest. New York: Routledge.

McDowell, L. (2008). Thinking through work: complex inequalities, constructions of difference and trans-national migrants. Progress in Human Geography, 32(4), 491-507.

- (2009). Working bodies: Interactive service employment and workplace identities. Oxford: Wiley-Blackwell.

Menacho, D. (1991). Indios. Una reflexión sobre el levantamiento inígena de 1990. Quito: ILDIS.

Mills, C. (1997). The racial contract. Ithaca, NY: Cornell University Press.

Moraña, M., Dussel, E., and Jáuregui, C. (2008). Colonialism and its replicants. In M. Moraña, E. Dussel, and C. Jáuregui (Eds.), Coloniality at large: Latin America and the postcolonial debate (pp. 1-22). Durham, NC: Duke University Press.

Mouffe, C. (1979). Gramsci and Marxist theory. London: Routledge.

- (1993). The return to the political. London: Verso.

. (1995). Post-Marxism: democracy and identity. Environment and Planning D: Society and Space, 13(3), 259-265.

- (2005a). On the political. New York: Routledge. . (2005b). The democratic paradox. London: Verso.

Müller, M. (2008). Reconsidering the concept of discourse for the field of critical geopolitics: towards discourse as language and practice. Political Geography, 27(3), 322-338.

- (2009). Making great power identities in Russia: an ethnographic discourse analysis of education at a Russian elite university. Zürich, Lit Verlag.

Nash, C. (2000). Performativity in practice: some recent work in cultural geography. Progress in Human Geography, 24(4), 653-664.

Natter, W. (1995). Radical democracy: hegemony, reason, time and space. Environment and Planning D: Society and Space, 13(3), 267-274.

Nelson, L. (1999). Bodies (and spaces) do matter: the limits of performativity. Gender, Place \& Culture, 6(4), 331-353.

Pateman, C. (1988). The sexual contract. Stanford: Stanford University Press.

Pateman, C. and Mills, C. (2007). Contract and domination. Cambridge: Polity Press. 
Pratt, G. (2004). Working feminism. Edinburgh: Edinburgh University Press.

Prieto, M. (2004). Liberalismo y temor: Imaginando los sujetos indígenas en el Ecuador postcolonial, 1895-1950. Quito: FLACSO.

Prieto, M. and Goetschel, A.M. (2008). El sufragio femenino en Ecuador, 18841940. In M. Prieto (Ed.), Mujeres y escenarios ciudadanos (pp. 299-330). Quito: FLACSO.

Pugh, J. (2005). The disciplinary effects of communicative planning in Soufriere, St Lucia: governmentality, hegemony and space-time-politics. Transactions of the Institute of British Geographers, 30(3), 307-321.

. (2007). On the political-by Chantal Mouffe. Area, 39(1), 130-131.

Radcliffe, S. (2000). Entangling resistance, ethnicity, gender and nation in Ecuador. In J. Sharp, P. Routledge, C. Philo, and R. Paddison (Eds.), Entanglements of power: geographies of domination/resistance (pp. 164-181). London: Routledge. . (2002). Indigenous women, rights and the Nation State in the Andes. In N. Craske and M. Molyneux (Eds.), Gender and the politics of rights and democracy in Latin America (pp. 149-172). Basingstoke: Palgrave.

. (2012). Development for a postneoliberal era? Sumak kawsay, living well and the limits to decolonisation in Ecuador. Geoforum, 43(2), 240-249.

Radcliffe, S., Laurie, N., and Andolina, R., (2002). Reterritorialised space and ethnic political participation: indigenous municipalities in Ecuador. Space \& Polity, 6(3), 289-305.

Radcliffe, S. and Westwood, S. (1996). Remaking the nation: place, identity and politics in Latin America. London: Routledge.

Rose, M. (2002). The seductions of resistance: power, politics, and a performative style of systems. Environment and Planning D: Society and Space, 20(4), 383-400.

Rose-Redwood, R.S. (2008). "Sixth Avenue is now a memory": regimes of spatial inscription and the performative limits of the official city-text. Political Geography, 27(8), 875-894.

Safa, H.I. (2005). Challenging mestizaje: a gender perspective on indigenous and afrodescendant movements in Latin America. Critique of Anthropology, 25(3), 307-330.

Scott, J. (1990). Domination and the arts of resistance. New Haven: Yale University Press.

Secor, A.J. (2003). Belaboring gender: the spatial practice of work and the politics of 'making do' in Istanbul. Environment and Planning A, 35(12), 2209-2227.

Sharp, J., Routledge, P., Philo, C., and Paddison, R. (2000). Entanglements of power: Geographies of domination/resistance. London: Routledge.

Staeheli, L. (1996). Publicity, privacy, and women's political action. Environment and Planning D: Society and Space, 14(5), 601-619.

Strüver, A. (2005). Stories of the "boring border": the Dutch-German borderscape in people's minds. Münster: Lit Verlag.

Swyngedouw, E. (2008). Where is the political?, Based on Antipode Lecture, IBG/ RGS annual conference 2007, London, August 29-September 1 and on James Blaut Memorial Lecture, Annual Conference of the AAG, Boston, April 16-21, 2008.

Thien, D. (2007). Disenchanting democracy. Area, 39(1), 134-135.

Van Cott, D.L. (2008). Radical democracy in the Andes. Cambridge: Cambridge University Press.

Walsh, C. (2003). Políticas (inter)culturales y gobiernos locales: experiencias ecuatorianas. In I.A. Mayor (Ed.), Políticas culturales urbanas: Experiencias Europeas y Americanas (pp. 110-119). Bogotá: IDCT/Alcaldía Mayor Bogotá. - (2008a). Interculturalidad, plurinacionalidad y decolonialidad: las insurgencias político-epistémicas de refundar el Estado. Tabula Rasa, 9 (julio-dic), $131-152$. 


\section{Carolin Schurr}

1

2

3

4

5

6

. (2008b). (Post)coloniality in Ecuador: the indigenous movement's practices and politics of (re)signification and decolonization. In M. Morana, E. Dussel, and C. Jáuregui (Eds.), Coloniality at large: Latin America and the postcolonial debate (pp. 506-518). Durham, NC: Duke University Press.

. (2009). The plurinational and intercultural State: decolonization and State re-founding in Ecuador. Kult 6. Special issue epistemologies of transformation: the Latin American decolonial option and its ramifications, 65-84.

Whitten, N., Scott Whitten, D., and Chango, A. (1997). Return of the Yumbo: the indigenous caminata from Amazonia to Andean Quito. American Ethnologist, 24(2), 355-391. 